\title{
Article \\ Development of a Culture Medium for Microalgae Production Based on Minimal Processing of Oil Palm Biomass Ash
}

\author{
Lorenzo Ferrari Assú Tessari, Carlos Ricardo Soccol, Cristine Rodrigues, Estefania García González, \\ Valcineide Oliveira de Andrade Tanobe, Paulo Cesar de Souza Kirnev and Júlio Cesar de Carvalho *
}

Citation: Tessari, L.F.A.; Soccol, C.R.; Rodrigues, C.; González, E.G.;

Tanobe, V.O.d.A.; Kirnev, P.C.d.S.; de Carvalho, J.C. Development of a Culture Medium for Microalgae Production Based on Minimal Processing of Oil Palm Biomass Ash. Fermentation 2022, 8, 55. https:// doi.org/10.3390/fermentation8020055 Academic Editors: Eldon R. Rene, Maria Carmen Veiga and Christian Kennes

Received: 24 December 2021 Accepted: 25 January 2022 Published: 27 January 2022

Publisher's Note: MDPI stays neutral with regard to jurisdictional claims in published maps and institutional affiliations.

Copyright: (C) 2022 by the authors. Licensee MDPI, Basel, Switzerland. This article is an open access article distributed under the terms and conditions of the Creative Commons Attribution (CC BY) license (https:// creativecommons.org/licenses/by/ $4.0 /)$.
Department of Bioprocess Engineering and Biotechnology, Federal University of Paraná, Brazil, Centro Politécnico, CP 19011, Curitiba 81531-980, PR, Brazil; lfa.tessari@gmail.com (L.F.A.T.); soccol@ufpr.br (C.R.S.); cristinelabor@gmail.com (C.R.); egarciagon@unal.edu.co (E.G.G.); valcitanobe@gmail.com (V.O.d.A.T.); kirnev@ufpr.br (P.C.d.S.K.)

* Correspondence: jccarvalho@ufpr.br

\begin{abstract}
With the increasing participation of biomass in the world energy matrix, large amounts of ash are produced through combustion, resulting in the need to dispose of this waste to minimize the environmental impact. An alternative is to use ashes as phosphorus supplements in microalgae cultures. The present work describes the development and use of a balanced culture medium based on the minimal processing of oil palm biomass ash to cultivate Arthrospira platensis Paracas, Neochloris oleoabundans UTEX 1185, and Dunaliella salina SAG 184. The acid extraction process of phosphorus $(\mathrm{P})$ was defined by evaluating the following parameters: temperature $\left(20\right.$ to $\left.70{ }^{\circ} \mathrm{C}\right)$, acid load ( 0.01 to 0.03 mols / g of ash) of $\mathrm{HNO}_{3}$, and liquid/solid ratio (50 to $150 \mathrm{~mL} \mathrm{~g}{ }^{-1}$ ). The best efficiency of the extraction process was $97 \%$. The use of $\mathrm{HNO}_{3}$ allowed for the production of an extract containing balanced amounts of $\mathrm{N}$ and $\mathrm{P}$ sources, the BAX medium (Biomass Ash Extract). This medium was efficient for cultivating the three microorganisms studied, reaching biomass concentrations of $2.03,0.902$, and $0.69 \mathrm{~g} / \mathrm{L}$ or $84 \%, 82 \%$, and $99 \%$ of the control concentrations for A. platensis, N. Oleoabundans, and D. salina, respectively. In a final scaling-up test, A. platensis showed productivity of $0.047 \mathrm{~g} \mathrm{~L}^{-1} \mathrm{~d}^{-1}$ in a $120 \mathrm{~L}$ tank in a greenhouse. BAX can be an alternative nutrient medium for microalgae cultivation, especially in integration with biomass-fueled biorefineries.
\end{abstract}

Keywords: phosphorus; microalgae; Dunaliella; Arthrospira; Neochloris; nitric acid

\section{Introduction}

Bioenergy participation in the world energy matrix has been growing by $8 \%$ yearly since 2006 [1]. It is estimated that by 2050, up to 33-50\% of the world's primary energy consumption could be provided by biomass $[2,3]$. Today, plant biomass used directly as an energy source contributes to $10 \%$ of the global energy supply. Part of this use is for cooking and heat, generating a scattered residue. However, much of the biomass is used in industries-16 to $18 \%$ in the United States of America, India, and Brazil in 2009 [4]. This industrial use generates large and localized volumes of ash, which must be disposed of. Biomass presents significant advantages mainly because of the reduction of $\mathrm{CO}_{2}$ emissions and reduced dependence on the use of fossil fuels [5].

The increased use of biomass, mainly by the industrial sector, also increases the amount of residual ash generated. Those wishing to apply ash to soil must consider the composition, which is variable and depends on factors such as soil type and composition, crop and cultivation method, season, and combustion temperature [6-9]. A possible use for biomass ash, rich in inorganic compounds, is its reintegration into the soil as a fertilizer. However, the residue is nutritionally unbalanced-virtually all the nitrogen is volatilized upon burning, and high concentrations of silicon, calcium, and aluminum are often present. Proper pretreatment is essential: although less toxic than coal ash, biomass ash can cause environmental problems [9]. 
On the other side, microalgal cultures-especially those envisaged for large-scale production of lipids for biodiesel production-demand large amounts of nutrients. Biomass ash can provide part of these nutrients, reducing the dependability on fertilizers that are obtained chiefly from mining, except for nitrogen (fixed via the Haber-Bosch process). The most important macroelements for microalgal cultures, besides carbon $\left(\right.$ as $\left.\mathrm{CO}_{2}\right)$, are nitrogen $(\mathrm{N})$, sodium $(\mathrm{Na})$, potassium $(\mathrm{K})$, calcium $(\mathrm{Ca})$, phosphorus $(\mathrm{P})$, sulfur $(\mathrm{S})$, magnesium $(\mathrm{Mg})$, and chlorine $(\mathrm{Cl})[10,11]$. Ash can provide most of these elements but cannot be used directly in liquid culture media because of low nutrient availability (low solubility) and particulate suspended solids' shading effects, which reduce light penetration and thus microalgae culture growth.

Of the nutrients recoverable from ash biomass, phosphorus is the most important for microalgal cultures. It is a non-renewable resource obtained mainly from mining. Researchers have proposed that the growing demand for this element in agronomy will exceed the global exploration capacity of mineral reserves in 50 to 100 years, a concept called "peak phosphorus" [12]. Little of the extracted P is returned to food and feed [13]. A large amount of $\mathrm{P}$ is transferred from mined resources to plants and animals through agriculture and the food chain, and most is lost along with its flow, ending up in agricultural leachates, immobilized in landfills, or is lost in industrial and municipal wastewaters. The phosphate content in worldwide freshwater systems is at least $75 \%$ higher than pre-industrial levels, and $\mathrm{P}$ flows in the oceans have increased from 8 to 22 million metric tons per year during the same time [14]. Therefore, the extraction of $\mathrm{P}$ from the ashes of plant biomass is an alternative to supply it for microalgae cultures, and it increase circularity.

The recovery of phosphates from waste streams is intensively researched, with municipal sludge ashes and biomass ashes representing promising nutrient sources. The recovery typically uses low-cost and efficient sulfuric acid $[15,16]$. Other acids can be used, such as hydrochloric [17], nitric [18], and even organic acids such as oxalic [19]. Among these acids, the only one that can also be used as a nitrogen source is nitric acid. Phosphates from liquid streams such as digestates from municipal wastewater plants can also be recovered as struvite [20-22].

One of the most abundant biomass sources available as fuel, thus generating large quantities of ash, is biomass fractions from oil palm (Elaeis guineensis). Palm oil is the most important vegetable oil worldwide, with an annual production of around 70 million tons and growing. Its wastes, such as EFB (Empty Fruit Bunch), palm fiber, palm shells, are generated in large amounts, since only $10 \%$ of the whole plant is used for oil production $[23,24]$. Palm processing industries need large amounts of steam, which is generated in boilers fueled by burning residues, preferentially the fibers from the pressing cake [24]. Searching for potential uses for lignocellulosic materials, many authors evaluated the composition of palm processing residues, including ashes. Significant amounts of potassium and phosphorus are found in the biomass ash (Table 1).

Table 1. Mineral Composition of oil palm biomasses and ash fractions.

\begin{tabular}{|c|c|c|c|c|c|c|c|c|c|c|}
\hline & [25] & & & [27] & [28] & [29] & [30] & [31] & [32] & [33] \\
\hline Components & EFB & EFB & PS & OPA & OPA & OPA & APA & POFA & POFA & POFA \\
\hline $\mathrm{SiO}_{2}$ & 12.12 & 27.00 & 49.70 & 86.44 & 35.60 & 37.00 & 40.00 & 64.17 & 67.72 & 40.00 \\
\hline $\mathrm{CaO}$ & 9.65 & 8.00 & 10.20 & - & 12.00 & 9.20 & 10.00 & 5.80 & 5.57 & 10.00 \\
\hline $\mathrm{K}_{2} \mathrm{O}$ & 55.48 & 44.00 & 12.20 & - & 11.00 & 11.00 & 12.10 & 8.25 & 7.67 & 12.10 \\
\hline $\mathrm{Al}_{2} \mathrm{O}_{3}$ & 0.26 & - & 7.70 & 6.49 & 4.80 & 14.30 & 6.10 & 3.73 & 3.71 & 6.10 \\
\hline $\mathrm{MgO}$ & 1.90 & 4.80 & 6.90 & 1.51 & 7.20 & 6.10 & 6.40 & 4.87 & 4.04 & 6.40 \\
\hline $\mathrm{P}_{2} \mathrm{O}_{5}$ & 3.58 & 3.60 & 8.40 & - & 6.80 & 6.20 & 8.32 & 5.18 & - & 8.20 \\
\hline $\mathrm{Fe}_{2} \mathrm{O}_{3}$ & - & 3.00 & 2.70 & 4.08 & 2.00 & 2.50 & - & 6.33 & 4.71 & 2.50 \\
\hline $\mathrm{SO}_{3}$ & 1.66 & 2.70 & - & 0.20 & - & - & - & 0.72 & 1.07 & - \\
\hline $\mathrm{Na}_{2} \mathrm{O}$ & 0.09 & - & - & 0.10 & - & 0.10 & - & 0.18 & 0.16 & - \\
\hline $\mathrm{Cl}$ & 6.84 & 5.30 & - & - & - & 2.90 & - & - & - & - \\
\hline
\end{tabular}


Table 1. Cont.

\begin{tabular}{|c|c|c|c|c|c|c|c|c|c|c|}
\hline \multirow[b]{2}{*}{ Components } & \multirow{2}{*}{$\begin{array}{l}\text { [25] } \\
\text { EFB }\end{array}$} & \multicolumn{2}{|c|}{ [26] } & \multirow{2}{*}{$\begin{array}{c}\text { [27] } \\
\text { OPA }\end{array}$} & \multirow{2}{*}{$\begin{array}{l}\text { [28] } \\
\text { OPA }\end{array}$} & \multirow{2}{*}{$\begin{array}{l}\text { [29] } \\
\text { OPA }\end{array}$} & \multirow{2}{*}{$\begin{array}{l}\text { [30] } \\
\text { APA }\end{array}$} & \multirow{2}{*}{$\begin{array}{c}\text { [31] } \\
\text { POFA }\end{array}$} & \multirow{2}{*}{$\begin{array}{c}\text { [32] } \\
\text { POFA }\end{array}$} & \multirow{2}{*}{$\begin{array}{c}\text { [33] } \\
\text { POFA }\end{array}$} \\
\hline & & EFB & PS & & & & & & & \\
\hline $\mathrm{C}$ & - & - & - & - & - & - & - & - & - & 5.40 \\
\hline $\mathrm{TiO}_{2}$ & - & - & - & - & - & - & - & 0.19 & - & - \\
\hline $\mathrm{MnO}$ & - & - & - & - & - & - & - & 0.18 & - & - \\
\hline $\mathrm{MnO}_{2}$ & - & - & - & 0.10 & - & - & - & - & - & - \\
\hline $\mathrm{ZnO}$ & - & - & - & - & - & - & - & 0.03 & - & - \\
\hline $\mathrm{Rb}_{2} \mathrm{O}$ & - & - & - & - & - & - & - & 0.06 & - & - \\
\hline $\mathrm{Cr}_{2} \mathrm{O}_{3}$ & - & - & - & 0.69 & - & - & - & 0.03 & - & - \\
\hline $\mathrm{Rh}_{2} \mathrm{O}_{3}$ & - & - & - & 0.41 & - & - & - & - & - & - \\
\hline $\mathrm{CuO}$ & - & - & - & - & - & - & - & 0.08 & - & - \\
\hline $\mathrm{RuO}_{2}$ & - & - & - & 0.29 & - & - & - & - & - & - \\
\hline $\mathrm{SrO}$ & - & - & - & - & - & - & - & 0.02 & - & - \\
\hline $\mathrm{ZrO}_{2}$ & - & - & - & - & - & - & - & $<0.01$ & - & - \\
\hline $\mathrm{NiO}$ & - & - & - & - & - & - & - & 0.02 & - & - \\
\hline $\mathrm{Y}_{2} \mathrm{O}_{3}$ & - & - & - & - & - & - & - & $<0.01$ & - & - \\
\hline
\end{tabular}
fuel ash.

Recovered, phosphorus can be used as a mineral nutrient for cultivating microalgae and cyanobacteria, since this is one of the essential elements in the cell composition [34,35]. On-site recovery also gives an alternative to value addition and zero-waste development in biorefineries, including a microalgal cultivation step and producing algal biomass rich in proteins, pigments, and even energetic and dietary lipids. Thus, the study's objective is to explore the use of nutrients present in minimally processed palm fiber ash to cultivate the cyanobacteria Arthospira platensis and the microalgae Neochloris oleoabundans and Dunaliella salina, with a focus on phosphorus recovery through treatment with nitric acid, thus developing a nitrogen-to-phosphorus balanced culture media based on minimal processing of biomass ash from the palm oil industry.

\section{Materials and Methods}

\subsection{Oil Palm Ash}

Ash from oil palm was obtained from BioPalma S.A., located in Moju, PA, Northern region of Brazil. Oil palm ash was collected and sieved to remove non-calcined materials, such as fibers. The granulometry distribution (Figure 1) was determined using a 6-screens lab sifter (Bertel VP-01, Lazanjeiras, SP, Brazil). Ashes used for extractions were homogenized lightly in a mortar. To remove the moisture eventually adsorbed, the ash was dried in a laboratory oven (Fanem Orion 502, Guarulhos, SP, Brazil) at $85^{\circ} \mathrm{C}$ for $15 \mathrm{~h}$.

The residue was analyzed by X-ray fluorescence spectrometry (FRX) (Table 2). The equipment used was an Axios Max (Malvern PANalytical, Almelo, Netherlands). The results were interpreted using the software SuperQ $51^{\circledR}$, from the same manufacturer.

Table 2. Composition of OPA

\begin{tabular}{cc}
\hline Components & wt $\%$ of Dry Solids \\
\hline $\mathrm{SiO} 2$ & 49.40 \\
$\mathrm{~K} 2 \mathrm{O}$ & 11.60 \\
$\mathrm{CaO}$ & 8.70 \\
$\mathrm{P} 2 \mathrm{O} 5$ & 8.60 \\
$\mathrm{MgO}$ & 5.80 \\
$\mathrm{Fe}_{2} \mathrm{O} 3$ & 5.60 \\
$\mathrm{Al}_{2} \mathrm{O} 3$ & 1.60 \\
$\mathrm{SO} 3$ & 1.60 \\
$\mathrm{Cl}$ & 0.70 \\
$\mathrm{TiO} 2$ & 0.20 \\
\hline
\end{tabular}


Table 2. Cont.

\begin{tabular}{cc}
\hline Components & wt \% of Dry Solids \\
\hline $\mathrm{MnO}$ & 0.10 \\
$\mathrm{SrO}$ & 0.10 \\
$\mathrm{Na}{ }_{2} \mathrm{O}$ & 0.10 \\
$\mathrm{ZrO} 2$ & $<0.10$ \\
$\mathrm{CuO}$ & $<0.10$ \\
$\mathrm{ZnO}$ & $<0.10$ \\
$\mathrm{LOI}$. & 5.99 \\
\hline
\end{tabular}

Note: LOI.: lost on ignition. Results normalized for $100 \%$.

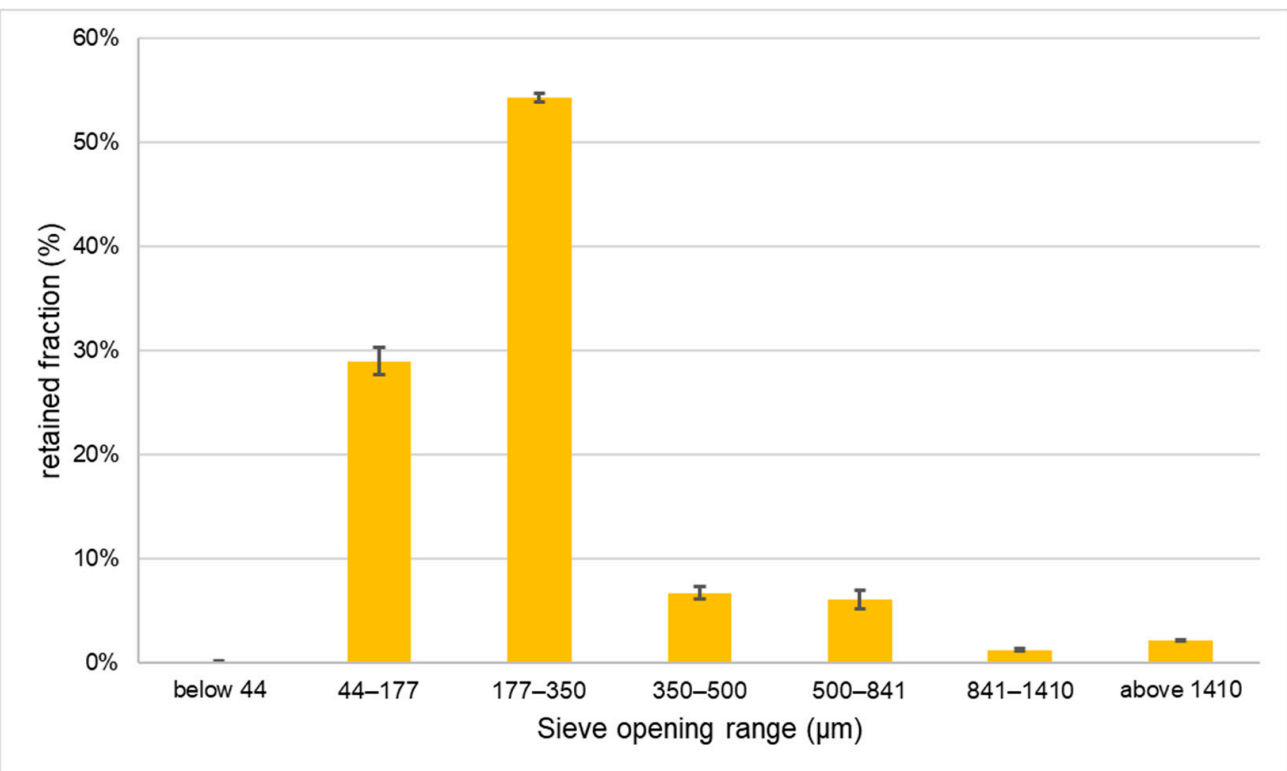

Figure 1. Particle size distribution of oil palm ash.

\subsection{Nutrient Extraction from Ash}

Ashes were leached to extract phosphate. A $3^{3}$ experimental design was used, based on conditions described in the literature for of acid extraction of phosphate from diverse ash materials [36-42]. The independent variables were temperature, mols of acid (as nitric acid), and Liquid/Solid Ratio (L/S). In all experiments, $1 \mathrm{~g}$ of ash was mixed with the acid and an adequate amount of Milli-Q water to reach the final intended volume. The levels of the variables are shown in Table 3.

Table 3. Conditions of the variables in the experiment.

\begin{tabular}{ccc}
\hline Temperature $\left({ }^{\circ} \mathbf{C}\right)$ & Moles of Acid & L/S ( $\left.\mathbf{m L ~} \mathbf{~ g}^{-\mathbf{1}}\right)$ \\
\hline 20 & 0.01 & 50 \\
45 & 0.02 & 100 \\
70 & 0.03 & 150 \\
\hline
\end{tabular}

The contact time was defined as $24 \mathrm{~h}$, previously defined as enough time for reaching quasi-equilibrium. After extraction, the mixtures were filtered through nitrocellulose membranes with $0.45 \mu \mathrm{m}$ pore size to separate the remaining ash from the extract. The extracts were analyzed for the quantification of phosphate.

\subsection{Kinetics of Phosphate Extraction}

The extraction kinetics of phosphate was evaluated to determine the minimum contact time necessary for extraction. The extraction was performed for $30 \mathrm{~h}$, using the mildest conditions of the initial factorial design (lower temperature and acid concentration, i.e., $20{ }^{\circ} \mathrm{C}$; 
0.01 moles of $\mathrm{HNO}_{3} ; \mathrm{L} / \mathrm{S} 150 \mathrm{~mL} \mathrm{~g}^{-1}$, periodic stirring). Samples were periodically collected in $2 \mathrm{~mL}$ Eppendorf tubes, centrifuged at 10,000 rpm for $5 \mathrm{~min}$, and the supernatant was evaluated for phosphate concentration.

\subsection{Microorganisms and Culture Media}

Three microorganisms suitable for cultivation on a large scale were used as models for studying ash extracts as culture media: the cyanobacterium Arthrospira platensis strain Paracas and the microalgae Neochloris oleoabundans UTEX 1185 and Dunaliella salina SAG 184.8.

Inoculum and control culture media: The inoculum of Arthrospira platensis was routinely maintained by successive culturing in Zarrouk medium [43], with initial pH 9.5 and at $30^{\circ} \mathrm{C}$. The inoculum of Neochloris oleoabundans was routinely maintained by successive cultures in BG11 medium [44], with initial pH 7.5 and at $25^{\circ} \mathrm{C}$. The inoculum of Dunaliella salina was routinely maintained by successive culturing in Modified Johnson's Medium (MJM) [45], adjusted to $\mathrm{pH} 7.1$ and at $25{ }^{\circ} \mathrm{C}$. The three cultures were maintained in $3 \mathrm{~L}$ Erlenmeyer flasks aerated with $1 \mathrm{vvm}$ of air and irradiation of $25 \mu \mathrm{mol}$ photons $\mathrm{m}^{-2} \mathrm{~s}^{-1}$. Control cultures for comparison with extracts had the same compositions and conditions, except for aeration - which was by diffusion, with daily manual homogenization.

BAX (Biomass Ash Extract) media: To evaluate the suitability of oil palm ash extracts as a nutrient source for microalgae growth, the extracts were diluted to match the control media concentration. The conditions for extraction were selected among the experiments that showed the highest phosphate solubilization efficiency in the factorial design. Contact time was $24 \mathrm{~h}$. The supernatant (extract) was filtered through a nitrocellulose membrane with $0.45 \mu \mathrm{m}$ pore size. The extract was separated into three fractions and diluted to match the theoretical usable concentration of P in each Control medium (Zarrouk, MJM, and BG11), respecting the Redfield ratio of 16 mols of nitrogen for each mol of phosphorus. The $\mathrm{pH}$ was adjusted with $10 \mathrm{M} \mathrm{NaOH}$ to match the initial $\mathrm{pH}$ in control cultures. Additionally, $87.7 \mathrm{~g} \mathrm{~L}^{-1} \mathrm{NaCl}$ was added for Dunaliella salina, specifically to maintain adequate salinity. Culture volume was $500 \mathrm{~mL}$ ( $450 \mathrm{~mL}$ culture medium $+50 \mathrm{~mL}$ inoculum) in $1 \mathrm{~L}$ Erlenmeyer flasks, with aeration by diffusion and gentle manual shaking every $24 \mathrm{~h}$. Initial concentrations were $0.09 \mathrm{~g} \mathrm{~L}^{-1}$ for both A. platensis and N. oleoabundans and $0.13 \mathrm{~g} \mathrm{~L}^{-1}$ for D. salina. Light intensity was $25 \mu \mathrm{mol}$ photons $\mathrm{m}^{-2} \mathrm{~s}^{-1}$, with continuous light, and constant temperature of $25^{\circ} \mathrm{C}$ for Neochloris oleoabundans, Dunaliella salina, and $30^{\circ} \mathrm{C}\left( \pm 5^{\circ} \mathrm{C}\right)$ for Arthrospira platensis. Each control and treatment were conducted in triplicate.

\subsection{Analytical Methods}

Phosphate was determined using a colorimetric assay with Malachite Green (Millipore Sigma, St. Louis, MI, USA) [46]. All tests were performed using genuine triplicates.

Microalgal biomass was evaluated by daily sampling and evaluating the absorbance at $670 \mathrm{~nm}$ (UV1601, Shimadzu, Kyoto, Japan) [47-49]. Dry mass analyses were performed every 6 days with $50 \mathrm{~mL}$ of sample. Samples were filtered through $3 \mu \mathrm{m}$ (A. platensis and $N$. oleoabundans) and $1 \mu \mathrm{m}(D$. salina) nitrocellulose membranes. The biomass was washed with $10 \mathrm{~mL}$ ammonium formate $\left(0.5 \mathrm{~mol} \mathrm{~L}^{-1}\right)$, dried for $24 \mathrm{~h}$ at $80^{\circ} \mathrm{C}$, and weighed [50].

\subsection{Statistical Analysis}

Experimental design planning and analysis were performed using the software Statistica ${ }^{\circledR}$ V. 7.0. Significant effects at the level of $5 \%$ confidence were considered through analysis of variance (ANOVA). All figures were prepared using MS-Excel ${ }^{\circledR}$ V. 16.0.

\section{Results and Discussion}

Preliminary tests using raw ash added with nitrogen sources showed poor microalgal growth, presumably because of self-shading caused by insoluble, suspended particulate material and poor nutrient leaching at culture $\mathrm{pH}$. To evaluate the suitability of culturing 
microalgae using nutrients from ash, we first evaluated and optimized the extraction, then tested extracts as the base for culture media, and finally chose conditions for scaling up.

\subsection{Phosphate Extraction}

It is well known that lower $\mathrm{pH}$ promotes more significant dissolution of $\mathrm{P}$ from ashes $[36,38,41,51,52]$. Typically, strong acids such as $\mathrm{H}_{2} \mathrm{SO}_{4}$ and $\mathrm{HCl}$ are used to dissolve phosphorus due to their low cost $[36,38,41,52,53]$. In this investigation, we used nitric acid: it is a strong acid, forms only soluble salts, and it is suitable as a nitrogen source for microalgal cultures, which would have to be added downstream if another acid were used as extractant. The temperature and liquid/solid ratio used were based on the literature, while the amount of acid was calculated based on the amount of phosphate theoretically extractable to give extracts respecting the Redfield ratio [54,55]. Table 4 shows the experimental conditions and results for a $3^{3}$ experimental design.

Table 4. $3^{3}$ experimental design for phosphate extraction.

\begin{tabular}{|c|c|c|c|c|c|}
\hline \multirow[b]{2}{*}{ Sample } & \multicolumn{3}{|c|}{ Experiment Conditions } & \multirow[b]{2}{*}{$\begin{array}{c}\text { Recovered } \\
\mathrm{P}_{2} \mathrm{O}_{5}(\mathrm{~g})\end{array}$} & \multirow[b]{2}{*}{$\begin{array}{l}\text { Dissolution of } \\
\mathrm{P}_{2} \mathrm{O}_{5}(\%)\end{array}$} \\
\hline & $\begin{array}{c}\text { Temperature } \\
\left({ }^{\circ} \mathrm{C}\right)\end{array}$ & $\begin{array}{l}\text { Acid Added, } \\
\text { Mols }\end{array}$ & $\begin{array}{c}\text { Liquid/Solid } \\
\left.\text { Ratio (mL g }{ }^{-1}\right)\end{array}$ & & \\
\hline 1 & 70 & 0.01 & 50 & 0.067 & 78.39 \\
\hline 2 & 70 & 0.01 & 100 & 0.065 & 75.31 \\
\hline 3 & 70 & 0.01 & 150 & 0.058 & 67.31 \\
\hline 4 & 70 & 0.02 & 150 & 0.084 & 97.52 \\
\hline 5 & 70 & 0.03 & 150 & 0.073 & 85.21 \\
\hline 6 & 70 & 0.03 & 100 & 0.069 & 79.94 \\
\hline 7 & 70 & 0.03 & 50 & 0.072 & 83.91 \\
\hline 8 & 70 & 0.02 & 50 & 0.073 & 85.18 \\
\hline 9 & 70 & 0.02 & 100 & 0.076 & 88.59 \\
\hline 10 & 45 & 0.01 & 50 & 0.059 & 68.76 \\
\hline 11 & 45 & 0.01 & 100 & 0.064 & 74.86 \\
\hline 12 & 45 & 0.01 & 150 & 0.057 & 66.64 \\
\hline 13 & 45 & 0.02 & 150 & 0.060 & 69.33 \\
\hline 14 & 45 & 0.03 & 150 & 0.065 & 76.04 \\
\hline 15 & 45 & 0.03 & 100 & 0.070 & 81.43 \\
\hline 16 & 45 & 0.03 & 50 & 0.069 & 79.88 \\
\hline 17 & 45 & 0.02 & 50 & 0.060 & 69.96 \\
\hline 18 & 45 & 0.02 & 100 & 0.065 & 75.46 \\
\hline 19 & 45 & 0.02 & 100 & 0.066 & 76.65 \\
\hline 20 & 45 & 0.02 & 100 & 0.065 & 75.31 \\
\hline 21 & 20 & 0.01 & 50 & 0.062 & 72.42 \\
\hline 22 & 20 & 0.01 & 100 & 0.059 & 68.90 \\
\hline 23 & 20 & 0.01 & 150 & 0.049 & 57.02 \\
\hline 24 & 20 & 0.02 & 150 & 0.063 & 73.35 \\
\hline 25 & 20 & 0.03 & 150 & 0.064 & 74.25 \\
\hline 26 & 20 & 0.03 & 100 & 0.074 & 86.50 \\
\hline 27 & 20 & 0.03 & 50 & 0.062 & 72.12 \\
\hline 28 & 20 & 0.02 & 50 & 0.062 & 72.27 \\
\hline 29 & 20 & 0.02 & 100 & 0.063 & 72.92 \\
\hline
\end{tabular}

Note: Samples 18, 19, and 20 represent triplicates of the central point in the factorial experiment.

The amount of $\mathrm{HNO}_{3}$ chosen was defined according to the foreseen formulation of culture media. Absolute amounts from 0.01 to 0.03 mols acid $\mathrm{g}^{-1}$ ash were estimated to reach the ideal N:P ratio. The acid concentrations ranged from 0.067 to $0.6 \mathrm{~mol} \mathrm{~L}^{-1}$. This reasoning made it possible to evaluate the L/S ratio without any conflict between variables simultaneously. An 8\% efficiency gain in dissolution between 0.01 and $0.02 \mathrm{~mol}$ was observed, but a slight increase of $2 \%$ from 0.02 to 0.03 mols of $\mathrm{HNO}_{3}$. With the L/S studied (50/1, 100/1, and 150/1), 0.02 and 0.03 mols of $\mathrm{HNO}_{3}$ presented better results. An analysis of the concentration showed that the highest initial acid concentrations did not necessarily give the best dissolution efficiencies: stoichiometry and temperature are more important.

Analyzing temperature, acid addition, and L/S ratio as variables influencing phosphorus extraction, the temperature was the variable that showed the most significant influence 
on the dissolution, followed by the number of mols, while L/S was not significant at $p=5 \%$. The increase in temperature from 20 to $45{ }^{\circ} \mathrm{C}$ promoted an increase of only $2 \%$ in the extraction, which may not justify the energy expenditure of a process where average temperatures can be maintained around $20^{\circ} \mathrm{C}$ (Figure 2). However, from 20 to $70{ }^{\circ} \mathrm{C}$, there is an increase of $10 \%$ in the dissolution efficiency of $\mathrm{P}$. The increase in temperature and acidity increases solubility of phosphorus from palm biomass ash, similarly to what was is described in the literature for sludge and biomass ashes [36,51].

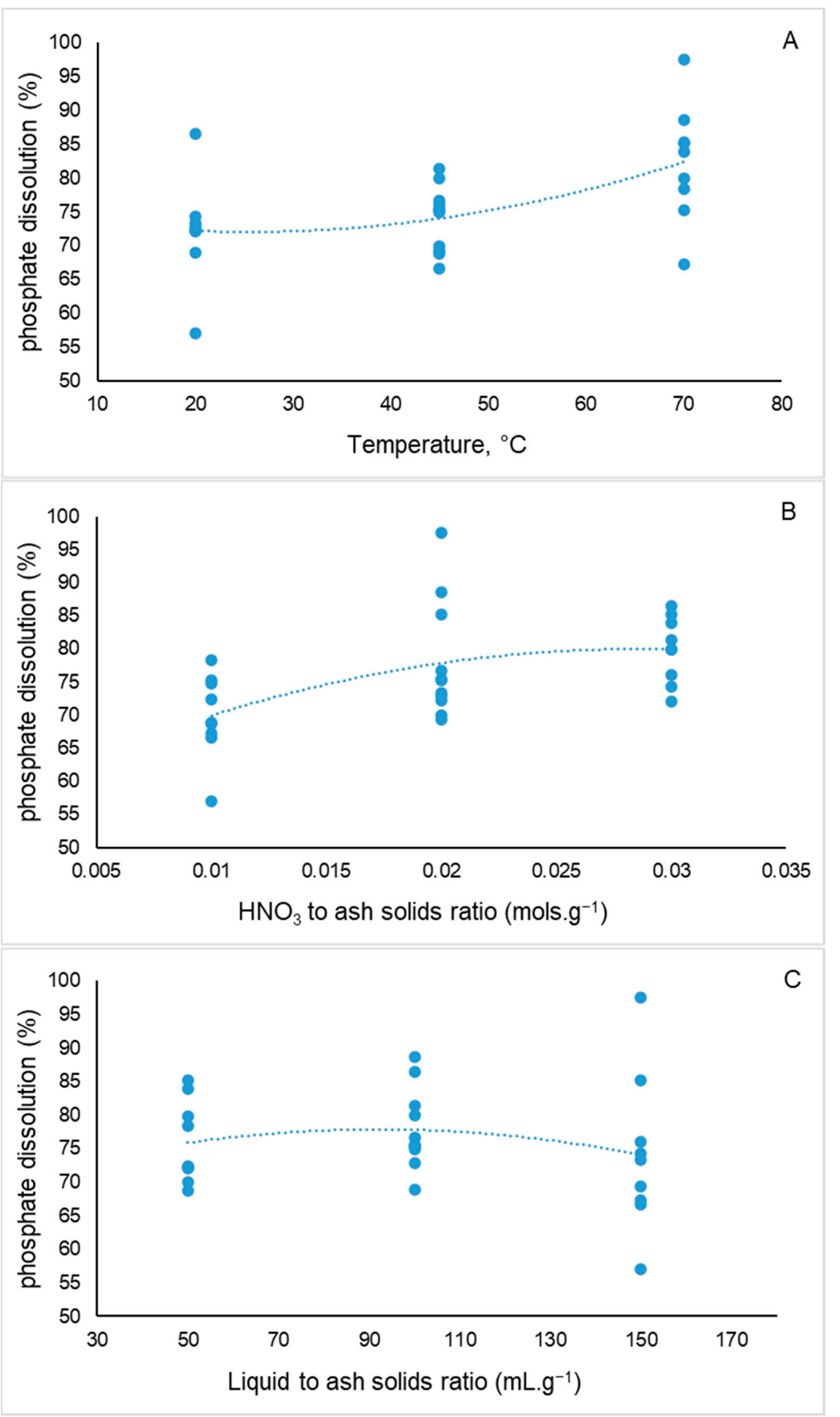

Figure 2. Phosphate dissolution is favored by higher temperatures (A) and higher acid content (B), but is not significantly affected by concentration (liquid to solids ratio, $(C)$ in the range evaluated. The dispersion of each group of points shows the effect of the two complementary variables, e.g., temperature and $\mathrm{HNO}_{3}$ : Ash in Figure 2C. 
The dissolution of $\mathrm{P}_{2} \mathrm{O}_{5}$ varied by $40 \%$. The lowest $\mathrm{P}$ dissolution occurred under $\mathrm{pH}$ 1.58, while the highest efficiency, 97\% (Table 4), was at $\mathrm{pH} 1.12$. Extraction yields near to $100 \%$ were reported at $\mathrm{pH} 1.0$ using $\mathrm{H}_{2} \mathrm{SO}_{4}$ to treat sewage sludge ash [38], with a far lower recovery $(40 \%)$ using $0.6 \mathrm{M} \mathrm{HNO}_{3}$, however, with an $\mathrm{L} / \mathrm{S}$ ratio of 5.0 , which is 10 to 30 times lower than what was used in this present study. In another study with sewage sludge ash, $0.0075 \mathrm{~mol}$ of $\mathrm{H}_{2} \mathrm{SO}_{4}$ in $150 \mathrm{~mL} \mathrm{~g}^{-1}$ and $0.015 \mathrm{~mol}$ of $\mathrm{HCl}$ in $150 \mathrm{~mL} \mathrm{~g}^{-1}$ gave satisfactory results, close to $100 \%$ phosphate dissolution [36]. A similar result was only obtained in the present study at $70^{\circ} \mathrm{C}$ with $0.02 \mathrm{~mol}$ of $\mathrm{HNO}_{3}$. This difference may have been due to the intermittent agitation: ash sedimentation may have reduced contact with the liquid. The extraction efficiency also likely varies for different materials because of different compositions [41] and acid neutralization by alkali oxides in the ashes.

The $\mathrm{L} / \mathrm{S}$ ratio showed no significant influence (at $\mathrm{P}=5 \%$ ) on the dissolution of $\mathrm{P}$ at the levels tested, presenting a slightly negative variation of $1.8 \%$ from 50 to $150 \mathrm{~mL} \mathrm{~g}^{-1}$. That could be explained not because the volume does not matter, but because all chemical species formed are soluble at the level tested, and that acid-to-ash stoichiometry and the consequent final $\mathrm{pH}$ is critical for this dissolution.

\subsection{Kinetics of Extraction}

The extraction efficiency was plotted against contact time for $30 \mathrm{~h}$ to evaluate the dissolution kinetics. The mildest extraction conditions were chosen: $20{ }^{\circ} \mathrm{C} ; 0.01$ mols of $\mathrm{HNO}_{3} ; 150 \mathrm{~mL} \mathrm{~g}^{-1}$. P dissolution is highly dependent on the contact time [36,52] and increases with time as an asymptotic curve (Figure 3). Only $15 \mathrm{~min}$ was enough to dissolve $45 \%$ of the phosphate, but $8 \mathrm{~h}$ were needed to reach the equilibrium concentration (an efficiency of $60 \%$ ). The relatively fast extraction of phosphorus may be due to its presence as soluble salts in the ashes [56] and the small particle size [41].

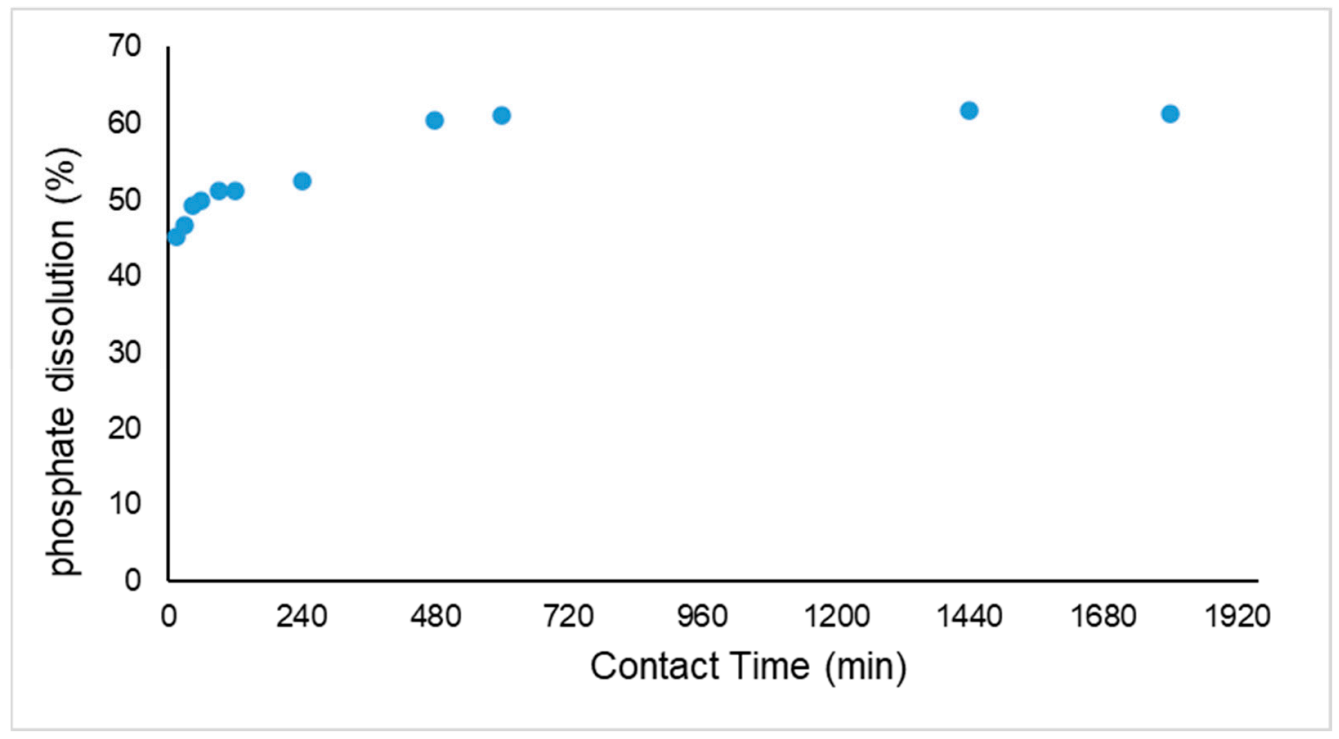

Figure 3. Kinetics of $\mathrm{P}$ dissolution.

\subsection{Cultivation of A. platensis, N. oleoabundans, and D. salina on BAX Medium}

Both nitrogen and phosphorus must be present in microalgae culture media. Although $\mathrm{H}_{2} \mathrm{SO}_{4}$ and $\mathrm{HCl}$ are more common for phosphate dissolution, the use of $\mathrm{HNO}_{3}$ as extractant acid allowed the supplementation of adequate amounts of nitrogen to cultivate cyanobacteria and microalgae. In balanced growth conditions, microalgae biomass has an average molar proportion of 106:16:1 (C:N:P) on its composition [34], although deviations exist $[55,57]$. After the extraction of $\mathrm{P}$, it was examined which conditions have the N:P ratio closest to 16 (Figure 4). 


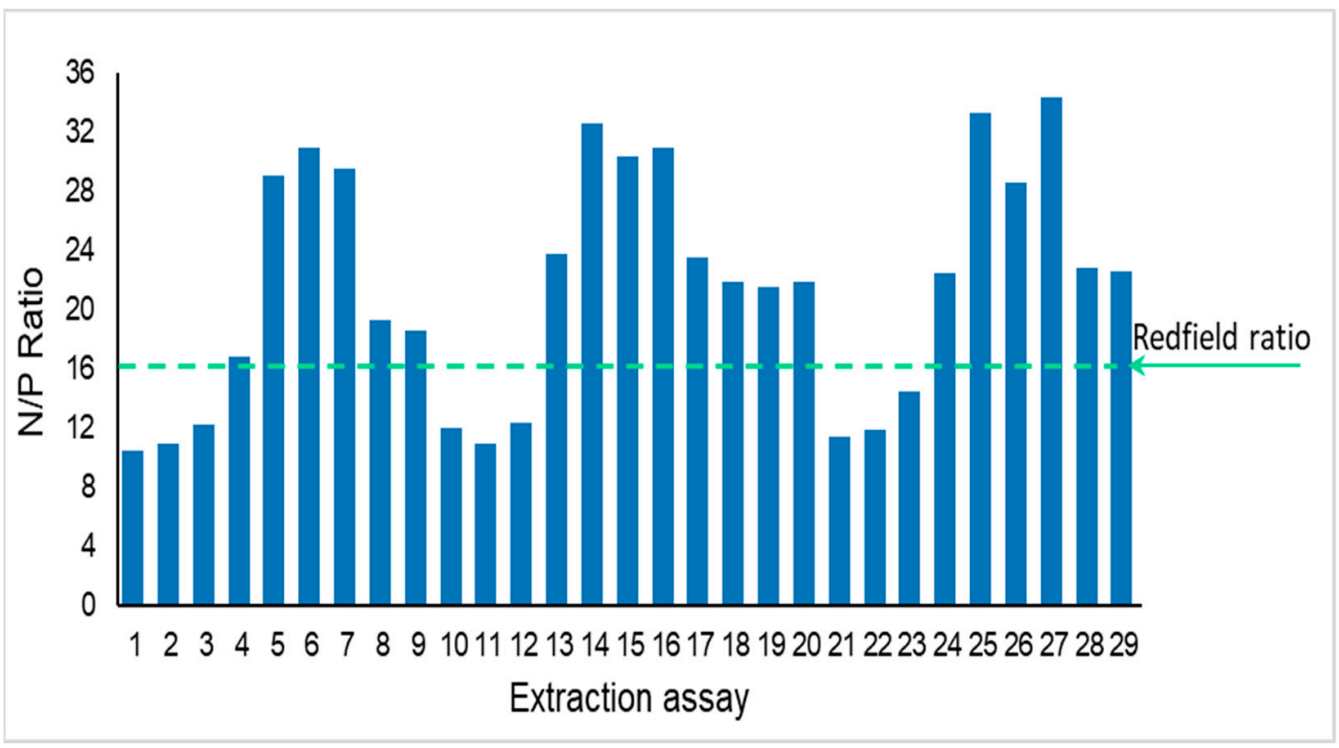

Figure 4. N:P ratio of the palm oil ash extracts.

Values above 16 mean nitrogen excess and below 16 mean phosphorus excess. Besides presenting the best extraction of $\mathrm{P}$, Condition 4 presented the best ratio for cultivation: 16.9 is near the Redfield ratio with a slight excess of nitrogen, recovering $97 \%$ of the $\mathrm{P}$ extracted from oil palm ash.

After adjusting the $\mathrm{pH}, \mathrm{BAX}$ was diluted $4.3,34.3$, and 30.6 times to match the theoretical usable concentration of $\mathrm{P}$ in each control medium (Zarrouk, BG11, and MJM, respectively), respecting the Redfield ratio. (Figure 5) shows the biomass production of A. platensis, N. oleoabundans, and D. salina in the BAX medium.

A. platensis: At the beginning of the cultivation (Figure 5A), both control (Zarrouk medium) and BAX were similar. The cyanobacteria initially had a low growth rate, probably due to the low initial cell concentration, of $0.09 \mathrm{~g} \mathrm{~L}^{-1}$. After 18 days, BAX cultivation growth started to slow down. The difference between control and BAX at this point is noticeable. On day 31, BAX cultivation reached $82 \%$ of the control biomass final concentration. Growth of Arthrospira sp. using POME (palm oil mill effluent) was observed in N:P ratios of 2.7:1 and 2.6:1 [58], while Zarrouk had an N:P ratio of 10:1. It is possible that A. platensis does not need an N:P ratio of 16:1, and the excess of nitrate in the BAX medium may have influenced the growth from day 18, promoting a slight reduction in biomass [59]. However, a hypothesis has been raised that the main reason for better growth in the Zarrouk medium is its initially large concentration of $\mathrm{CO}_{2}$ as sodium bicarbonate.

$N$. oleoabundans: From day 4 to 8 , the BAX culture exhibited a slightly reduced growth compared to the control (BG11 medium), probably due to the process of acclimatizing the cells to the new medium. After day 12, N. oleoabundans elevated the growth rate and finished the 31 days of culture with $0.9 \mathrm{~g} \mathrm{~L}^{-1}$, while the control had $1 \mathrm{~g} \mathrm{~L}^{-1}$ (Figure 5B). Kinetics of cyanobacterial and microalgal growth was examined with poultry litter ash and showed better results when the $\mathrm{N}$ source was only ammonium [60]. However, the authors reported that $2.5 \mathrm{~g} \mathrm{~L}^{-1} \mathrm{NaNO}_{3}$ was added to prevent nitrogen limitation, $100 \mathrm{mg} \mathrm{L}^{-1}$ $\mathrm{Na}_{2}$-EDTA was added as a chelating agent, and cultures had aeration of $2 \mathrm{~L}$ of air $\mathrm{min}^{-1}$ and luminous intensity of $121.5 \mu \mathrm{mol}$ photons $\mathrm{m}^{-2} \mathrm{~s}^{-1}$, far superior than the diffusion aeration and $27 \mu \mathrm{mol}$ photons $\mathrm{m}^{-2} \mathrm{~S}^{-1}$ used in the present study.

D. salina: (Figure 5C) shows that this microalga had the best growth in the BAX medium compared to the control (MJM medium). The cultures had similar growth since day 0 , reaching final concentrations of 0.69 and $0.70 \mathrm{~g} \mathrm{~L}^{-1}$, respectively. 


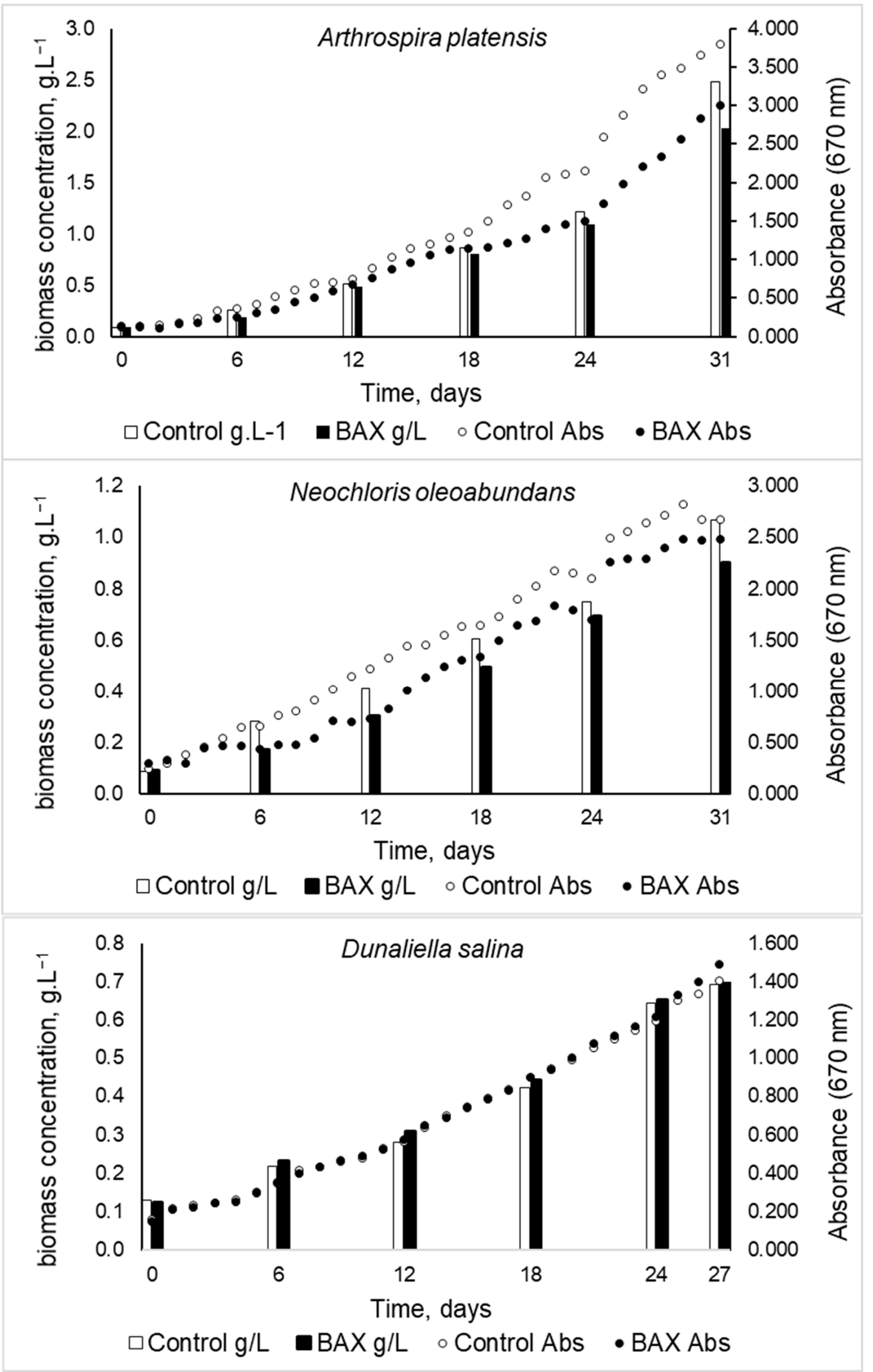

(A)

(B)

(C)

Figure 5. Biomass production of Arthrospira platensis (A), Neochloris oleoabundans (B) and Dunaliella salina (C) on control (synthetic) and BAX medium. All results are average of triplicates. 
For all microorganisms, 27 to 31 days of cultivation, without agitation or forced aeration, was necessary to evaluate the behavior of long-term cultures. All considered, the biomass production and growth rate were comparable in BAX and control media, and to the authors' best knowledge, there are no published data of oil palm Ash used to grow cyanobacteria and microalgae. The results were satisfactory and proved that phosphorus in the ashes could be used to grow cyanobacteria and microalgae at rates close to or equivalent to widely popular media.

\subsection{Scaling Up}

The scaleup (120 L, open tank, greenhouse) was carried out to verify growth replicability in large scale, and also two hypotheses: (1) to verify if the aeration would compensate the limitation of the growth of the microalga cultivated in BAX medium when compared with the Zarrouk medium (limitation observed in the laboratory), and (2) because of the ability of Arthorspira to basify the medium to higher values ( $\mathrm{pH} 11$ ), to verify the possibility of reduced growth due to reduced availability of phosphate because of alkaline precipitation as $\mathrm{Ca}$ or $\mathrm{Mg}$ salts.

In growing on a larger scale (Figure 6), the growth pattern was similar to that observed in the laboratory, but the initial cell concentration was higher $\left(0.22 \mathrm{~g} \mathrm{~L}^{-1}\right)$. After 25 days of cultivation, the concentration obtained was $1.40 \mathrm{~g} \mathrm{~L}^{-1}$ and the productivity $0.0472 \mathrm{~g} \mathrm{~L}^{-1} \mathrm{~d}^{-1}$, both similar to the laboratory scale culture in the same period. At 31 days of culture, the final cellular concentration observed was $1.6 \mathrm{~g} \mathrm{~L}^{-1}$, corresponding to $80 \%$ of the value obtained in the culture on the laboratory scale. The difference of $20 \%$ in the cellular concentration between the scales evaluated can be attributed to natural temperature variability from 22 to $36.7^{\circ} \mathrm{C}$, with an average of $36.7^{\circ} \mathrm{C}$, which may have caused a decrease in culture growth-Arthorspira requires temperatures between 30 and $38{ }^{\circ} \mathrm{C}$ for optimal growth [61]. Another critical factor is that the cultivation on an enlarged scale was conditioned to a natural photoperiod of $13 \mathrm{~h} / 11 \mathrm{~h}$, unlike laboratory cultures where irradiation was constant during the 31 days.

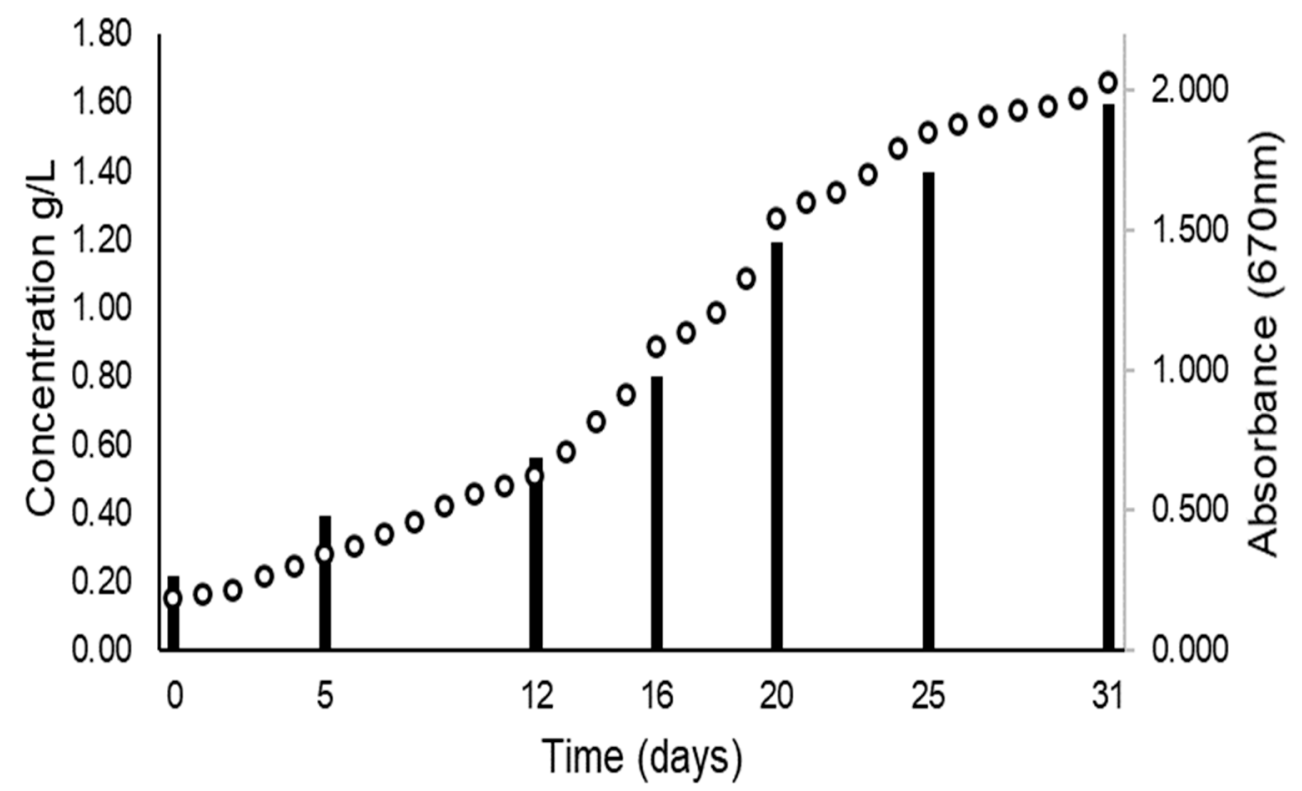

Figure 6. Growth kinetics of scaled-up A. platensis cultivation conducted in a greenhouse with a BAX medium.

\subsection{Practical Applications and Future Research}

Microalgae are intensively researched as potential food, feed and bioenergy sources. However, one of the drawbacks of large-scale cultures of microalgae is the requirement for nutrients, which increases costs and makes only a few biomass products commercially 
viable at the moment. The successful cultivation of three important microalgae in ashextract based culture media (BAX) shows that commercial fertilizers can be substituted as nutrient sources for microalgae, and that the judicious use of nitric acid is adequate to enhance extraction and provide a nitrogen source. BAX could be prepared using other acids, such as sulfuric acid; however, a nitrogen source would have to be added tom complete a culture medium. The use of ash increases the circularity of processes, recovering phosphorus; the high yield shows that a similar process could also be used for recovery of phosphorus for other uses.

The BAX medium is simple to prepare, requiring only $\mathrm{pH}$ correction and, for marine microalgae, salt addition. It recycles phosphorus and other mineralized nutrients otherwise lost in biomass ash wastes. However, there are several aspects than can be improved; the three most important are

(i) Scale-up was similar to laboratory cultures, but with modest productivity. It is possible that warmer temperatures lead to better growth. Repeated batches in a long running experiment will also show if some nutrient lacking, e.g., sodium for Spirulina, or in excess such as iron (usually present in low concentrations in synthetic media) limit the growth or affect the composition.

(ii) Oil palm ash has a high concentration of potassium, a most needed element in plant fertilizers, but not important enough for microalgae growth. Fractionation of palm ash, e.g., through selective or sequential extraction could make even better use of this residue and maybe integrate it to palm production, reducing the need for fertilizer.

(iii) Large-scale processing of palm oil ash would require reactors, pumps, and filters. Even if the equipment is simple compared to the large-scale equipment used in palm processing, it involves a capital cost that would have to be compensated by the income from biomass products. This requires a process simulation and sensitivity analysis to indicate if microalgae production, although technically feasible, can be profitable in its biorefinery integration with palm processing.

\section{Conclusions}

This proof-of-concept study proved that minimally processed palm ash could be used in microalgae production. Because liquid media and nitrate as nitrogen source are required, it is sufficient to treat the ash with nitric acid. Phosphorus dissolution by $\mathrm{HNO}_{3}$ presented satisfactory results at a temperature of $70{ }^{\circ} \mathrm{C}$ and an $\mathrm{HNO}_{3}$ concentration of $0.2 \mathrm{M}$ (a mass proportion of $1.26: 1 \mathrm{HNO}_{3}$ :ash). In these conditions, up to $97 \%$ of the phosphorus was dissolved after $24 \mathrm{~h}$. Lower temperatures $\left(20^{\circ} \mathrm{C}\right)$ are enough to extract about $72 \%$ of the phosphate, and $8 \mathrm{~h}$ was shown to be enough to reach equilibrium in the mildest conditions. The use of the BAX medium was shown to be efficient for the three microorganisms studied, giving biomass production and productivity similar to control cultures performed in synthetic media, albeit with room for improvement. A scaled-up, $120 \mathrm{~L}$ cultivation of $A$. platensis conducted in a greenhouse confirmed the feasibility of this residue use approach.

Author Contributions: Main experimental investigation, analysis, writing, L.F.A.T.; conceptualization, revision, funding, C.R.S.; writing, analyses, C.R.; writing, revision, E.G.G.; analyses, revision, V.O.d.A.T.; writing, revision, P.C.d.S.K.; conceptualization, project management, revision, J.C.d.C. All authors have read and agreed to the published version of the manuscript.

Funding: This work was supported by CNPq, the Brazilian National Council for Scientific and Technological Development, grant numbers 407543/2013-0 and 314147/2018-7, and CAPES, the Coordination of Improvement of Higher Education Personnel-PROEX program.

Conflicts of Interest: The authors declare no conflict of interest.

\section{References}

1. Birol, F.; Cozzi, L.; Gould, T.; Bromhead, A.; Priddle, R. World Energy Outlook 2015; Organisation for Economic Cooperation and Development: Paris, France, 2015. 
2. McKendry, P. Energy production from biomass (part 1): Overview of biomass. Bioresour. Technol. 2002, 83, 37-46. [CrossRef]

3. Vassilev, S.V.; Baxter, D.; Andersen, L.K.; Vassileva, C.G. An overview of the composition and application of biomass ash. Part 1. Phase-mineral and chemical composition and classification. Fuel 2013, 105, 40-76. [CrossRef]

4. Schill, S.R.; IEA Task 40: Biomass Provides 10 Percent of Global Energy Use. Biomass Magazine. Grand Forks 2013. Available online: http:/ / biomassmagazine.com/articles/9444/iea-task40-biomass-provides-10-percent-of-global-energy-use (accessed on 20 January 2022).

5. Chuah, T.G.; Wan Azlina, A.G.K.; Robiah, Y.; Omar, R. Biomass as the renewable energy sources in Malaysia: An overview. Int. J. Green Energy 2006, 3, 323-346. [CrossRef]

6. Siddique, R. Utilization of wood ash in concrete manufacturing. Resour. Conserv. Recycl. 2012, 67, 27-33. [CrossRef]

7. Wiselogel, A.E.; Agblevor, F.A.; Johnson, D.K.; Deutch, S.; Fennell, J.A.; Sanderson, M.A. Compositional changes during storage of large round switchgrass bales. Bioresour. Technol. 1996, 56, 103-109. [CrossRef]

8. Thy, P.; Jenkins, B.M.; Grundvig, S.; Shiraki, R.; Lesher, C.E. High temperature elemental losses and mineralogical changes in common biomass ashes. Fuel 2006, 85, 783-795. [CrossRef]

9. Ahmaruzzaman, M. A review on the utilization of fly ash. Prog. Energy Combust. Sci. 2010, 36, 327-363. [CrossRef]

10. Grobbelaar, J.U. Algal nutrition-mineral nutrition. In Handbook of Microalgal Culture: Biotechnology and Applied Phycology; Blackwell Publishing: Oxford, UK, 2004; pp. 95-115.

11. De Carvalho, J.C.; Sydney, E.B.; Assú Tessari, L.F.; Soccol, C.R. Culture media for mass production of microalgae. In Biomass, Biofuels, Biochemicals, 2nd ed.; Pandey, A., Chang, J.-S., Soccol, C.R., Lee, D.-J., Chisti, Y.B.T.-B., Eds.; Elsevier: Amsterdam, The Netherlands, 2019; pp. 33-50. ISBN 978-0-444-64192-2.

12. Cordell, D.; Drangert, J.O.; White, S. The story of phosphorus: Global food security and food for thought. Glob. Environ. Chang. 2009, 19, 292-305. [CrossRef]

13. Rittmann, B.E.; Mayer, B.; Westerhoff, P.; Edwards, M. Capturing the lost phosphorus. Chemosphere 2011, 84, 846-853. [CrossRef]

14. Bennett, E.M.; Carpenter, S.R.; Caraco, N.F. Human impact on erodable phosphorus and eutrophication: A global perspective. Bioscience 2001, 51, 227-234. [CrossRef]

15. Liu, H.; Hu, G.; Basar, I.A.; Li, J.; Lyczko, N.; Nzihou, A.; Eskicioglu, C. Phosphorus recovery from municipal sludge-derived ash and hydrochar through wet-chemical technology: A review towards sustainable waste management. Chem. Eng. J. 2021, 417, 129300. [CrossRef]

16. Leng, L.; Bogush, A.A.; Roy, A.; Stegemann, J.A. Characterisation of ashes from waste biomass power plants and phosphorus recovery. Sci. Total. Environ. 2019, 690, 573-583. [CrossRef] [PubMed]

17. Lee, M.; Kim, D.-J. Identification of phosphorus forms in sewage sludge ash during acid pre-treatment for phosphorus recovery by chemical fractionation and spectroscopy. J. Ind. Eng. Chem. 2017, 51, 64-70. [CrossRef]

18. Gorazda, K.; Tarko, B.; Wzorek, Z.; Nowak, A.K.; Kulczycka, J.; Henclik, A. Characteristic of wet method of phosphorus recovery from polish sewage sludge ash with nitric acid. Open Chem. 2016, 14, 37-45. [CrossRef]

19. Liang, S.; Chen, H.; Zeng, X.; Li, Z.; Yu, W.; Xiao, K.; Hu, J.; Hou, H.; Liu, B.; Tao, S. A comparison between sulfuric acid and oxalic acid leaching with subsequent purification and precipitation for phosphorus recovery from sewage sludge incineration ash Water Res. 2019, 159, 242-251. [CrossRef]

20. Melia, P.M.; Cundy, A.B.; Sohi, S.P.; Hooda, P.S.; Busquets, R. Trends in the recovery of phosphorus in bioavailable forms from wastewater. Chemosphere 2017, 186, 381-395. [CrossRef]

21. Carey, D.E.; Yang, Y.; McNamara, P.J.; Mayer, B.K. Recovery of agricultural nutrients from biorefineries. Bioresour. Technol. 2016, 215, 186-198. [CrossRef]

22. Marchi, A.; Geerts, S.; Saerens, B.; Weemaes, M.; De Clercq, L.; Meers, E. Struvite recovery from domestic wastewater. In Biorefinery of Inorganics: Recovering Mineral Nutrients from Biomass and Organic Waste; John Wiley \& Sons, Inc.: Hoboken, NJ, USA, 2020; pp. 107-119.

23. Aziz, M.; Kurniawan, T.; Oda, T.; Kashiwagi, T. Advanced power generation using biomass wastes from palm oil mills. Appl. Therm. Eng. 2016, 114, 1378-1386. [CrossRef]

24. Letti, L.A.J.; Woiciechowski, A.L.; Medeiros, A.B.P.; Rodrigues, C.; de Carvalho, J.C.; de Souza Vandenberghe, L.P.; Karp, S.G.; Torres, L.A.Z.; Guarnizo, A.F.C.; Colonia, B.S.O. Valorization of solid and liquid wastes from palm oil industry. In Waste Biorefinery; Elsevier: Amsterdam, The Netherlands, 2021; pp. 235-265.

25. Madhiyanon, T.; Sathitruangsak, P.; Sungworagarn, S.; Pipatmanomai, S.; Tia, S. A pilot-scale investigation of ash and deposition formation during oil-palm empty-fruit-bunch (EFB) combustion. Fuel Process. Technol. 2012, 96, 250-264. [CrossRef]

26. Lahijani, P.; Zainal, Z.A.; Mohamed, A.R.; Mohammadi, M. Ash of palm empty fruit bunch as a natural catalyst for promoting the $\mathrm{CO}_{2}$ gasification reactivity of biomass char. Bioresour. Technol. 2013, 132, 351-355. [CrossRef]

27. Acquah, C.; Sie Yon, L.; Tuah, Z.; Ling Ngee, N.; Danquah, M.K. Synthesis and performance analysis of oil palm ash (OPA) based adsorbent as a palm oil bleaching material. J. Clean. Prod. 2016, 139, 1098-1104. [CrossRef]

28. Mohamed, A.R.; Lee, K.T.; Noor, N.M.; Zainudin, N.F. Oil palm ash $/ \mathrm{Ca}(\mathrm{OH})_{2} / \mathrm{CaSO}_{4}$ absorbent for flue gas desulfurization. Chem. Eng. Technol. 2005, 28, 939-945. [CrossRef]

29. Lee, K.T.; Bhatia, S.; Mohamed, A.R. Preparation and characterization of sorbents prepared from ash (waste material) for sulfur dioxide $\left(\mathrm{SO}_{2}\right)$ removal. J. Mater. Cycles Waste Manag. 2005, 7, 16-23. [CrossRef] 
30. Hameed, B.H.; Ahmad, A.A.; Aziz, N. Isotherms, kinetics and thermodynamics of acid dye adsorption on activated palm ash. Chem. Eng. J. 2007, 133, 195-203. [CrossRef]

31. Ranjbar, N.; Mehrali, M.; Alengaram, U.J.; Metselaar, H.S.C.; Jumaat, M.Z. Compressive strength and microstructural analysis of fly ash/palm oil fuel ash based geopolymer mortar under elevated temperatures. Constr. Build. Mater. 2014, 65, 114-121. [CrossRef]

32. Bashar, I.I.; Alengaram, U.J.; Jumaat, M.Z.; Islam, A.; Santhi, H.; Sharmin, A. Engineering properties and fracture behaviour of high volume palm oil fuel ash based fibre reinforced geopolymer concrete. Constr. Build. Mater. 2016, 111, 286-297. [CrossRef]

33. Zainudin, N.F.; Lee, K.T.; Kamaruddin, A.H.; Bhatia, S.; Mohamed, A.R. Study of adsorbent prepared from oil palm ash (OPA) for flue gas desulfurization. Sep. Purif. Technol. 2005, 45, 50-60. [CrossRef]

34. Tyrrell, T. Redfield ratio. In Encyclopedia of Ocean Sciences; Steele, J.H., Thorpe, S.A., Turekian, K.K., Eds.; Academic Press: San Diego, CA, USA, 2001; Volume 83, pp. 2377-2387.

35. Richmond, A.; Hu, Q. Handbook of Microalgal Culture. Richmond, A., Hu, Q., Eds.; Wiley: New York, NY, USA, 2013; ISBN 0632059532.

36. Biswas, B.K.; Inoue, K.; Harada, H.; Ohto, K.; Kawakita, H. Leaching of phosphorus from incinerated sewage sludge ash by means of acid extraction followed by adsorption on orange waste gel. J. Environ. Sci. 2009, 21, 1753-1760. [CrossRef]

37. Matjie, R.H.; Bunt, J.R.; Van Heerden, J.H.P. Extraction of alumina from coal fly ash generated from a selected low rank bituminous South African coal. Miner. Eng. 2005, 18, 299-310. [CrossRef]

38. Ottosen, L.M.; Kirkelund, G.M.; Jensen, P.E. Extracting phosphorous from incinerated sewage sludge ash rich in iron or aluminum. Chemosphere 2013, 91, 963-969. [CrossRef]

39. Parés Viader, R.; Jensen, P.E.; Ottosen, L.M.; Ahrenfeldt, J.; Hauggaard-Nielsen, H. Electrodialytic extraction of phosphorus from ash of low-temperature gasification of sewage sludge. Electrochimica Acta 2015, 181, 100-108. [CrossRef]

40. Wzorek, Z.; Jodko, M.; Gorazda, K.; Rzepecki, T. Extraction of phosphorus compounds from ashes from thermal processing of sewage sludge. J. Loss Prev. Process Ind. 2006, 19, 39-50. [CrossRef]

41. Xu, H.; He, P.; Gu, W.; Wang, G.; Shao, L. Recovery of phosphorus as struvite from sewage sludge ash. J. Environ. Sci. 2012, 24, 1533-1538. [CrossRef]

42. Xu, Y.; Hu, H.; Liu, J.; Luo, J.; Qian, G.; Wang, A. Ph dependent phosphorus release from waste activated sludge: Contributions of phosphorus speciation. Chem. Eng. J. 2015, 267, 260-265. [CrossRef]

43. Zarrouk, C. Contribution à l'étude d'une Cyanophycée. Influence de Divers Facteurs Physiques et Chimiques Sur la Croissance et la Photosynthèse de Spirulina maxima. Ph.D. Thesis, Université de Paris, Paris, France, 1996.

44. Stanier, R.; Kunisawa, R.; Mandel, M.; Cohen-Bazire, G. BG11 (blue green medium). Cult. Collect. Algae Protozoa 1971, $11,559001$.

45. Borowitzka, M.A.; Borowitzka, L.J. Micro-Algal Biotechnology; Cambridge University Press: Cambridge, UK, 1988; ISBN 0521323495.

46. D'Angelo, E.; Crutchfield, J.; Vandiviere, M. Rapid, sensitive, microscale determination of phosphate in water and soil. J. Environ. Qual. 2001, 30, 2206-2209. [CrossRef]

47. De Freitas, B.C.B.; Brächer, E.H.; de Morais, E.G.; Atala, D.I.P.; de Morais, M.G.; Costa, J.A.V. Cultivation of different microalgae with pentose as carbon source and the effects on the carbohydrate content. Environ. Technol. 2019, 40, 1062-1070. [CrossRef]

48. Silva, H.R.; Prete, C.E.C.; Zambrano, F.; de Mello, V.H.; Tischer, C.A.; Andrade, D.S. Combining glucose and sodium acetate improves the growth of Neochloris oleoabundans under mixotrophic conditions. AMB Express 2016, 6, 10. [CrossRef]

49. Walter, A.; De Carvalho, J.C.; Soccol, V.T.; De Faria, A.B.B.; Ghiggi, V.; Soccol, C.R. Study of phycocyanin production from Spirulina platensis under different light spectra. Braz. Arch. Biol. Technol. 2011, 54, 675-682. [CrossRef]

50. Zhu, C.J.; Lee, Y.K. Determination of biomass dry weight of marine microalgae. J. Appl. Phycol. 1997, 9, 189-194. [CrossRef]

51. Tan, Z.; Lagerkvist, A. Phosphorus recovery from the biomass ash: A review. Renew. Sustain. Energy Rev. 2011, 15, 3588-3602. [CrossRef]

52. Cohen, Y. Phosphorus dissolution from ash of incinerated sewage sludge and animal carcasses using sulphuric acid. Environ. Technol. 2009, 30, 1215-1226. [CrossRef]

53. Egle, L.; Rechberger, H.; Zessner, M. Overview and description of technologies for recovering phosphorus from municipal wastewater. Resour. Conserv. Recycl. 2015, 105, 325-346. [CrossRef]

54. Redfield, A.C. The biological control of chemical factors in the environment. Am. Sci. 1958, 46, $205-221$.

55. Geider, R.J.; La Roche, J. Redfield revisited: Variability of C:N:P in marine microalgae and its biochemical basis. Eur. J. Phycol. 2002, 37, 1-17. [CrossRef]

56. Hong, K.-J.; Tarutani, N.; Shinya, Y.; Kajiuchi, T. Study on the recovery of phosphorus from waste-activated sludge incinerator ash. J. Environ. Sci. Health Part A 2005, 40, 617-631. [CrossRef]

57. Hedges, J.I.; Baldock, J.A.; Gélinas, Y.; Lee, C.; Peterson, M.L.; Wakeham, S.G. The biochemical and elemental compositions of marine plankton: A NMR perspective. Mar. Chem. 2002, 78, 47-63. [CrossRef]

58. Azimatun Nur, M.M. Evaluation of carbon, nitrogen and phosphorus ratio of palm oil mill effluent digested (POMED) wastewater as replacement synthetic medium for Spirulina sp. growth. Am. J. Agric. Environ. Sci. 2014, 14, 536-540. [CrossRef]

59. Jeanfils, J.; Canisius, M.F.; Burlion, N. Effect of high nitrate concentrations on growth and nitrate uptake by free-living and immobilized Chlorella vulgaris cells. J. Appl. Phycol. 1993, 5, 369-374. [CrossRef] 
60. Markou, G.; Iconomou, D.; Sotiroudis, T.; Israilides, C.; Muylaert, K. Exploration of using stripped ammonia and ash from poultry litter for the cultivation of the cyanobacterium Arthrospira platensis and the green microalga Chlorella vulgaris. Bioresour. Technol. 2015, 196, 459-468. [CrossRef]

61. Colla, L.M.; Furlong, E.B.; Alberto, J.; Costa, V. Antioxidant properties of Spirulina (Arthospira) platensis cultivated under different temperatures and nitrogen regimes. Braz. Arch. Biol. Technol. 2007, 50, 161-167. [CrossRef] 